Przegląd Badań Edukacyjnych Educational Studies Review

ISSN 1895-4308

nr 30 (1/2020), s. 161-175

METAANALIZY

BADAŃ

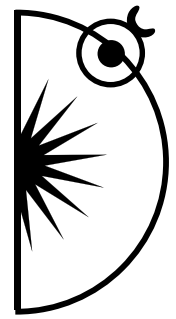

Grażyna Kosiba

ORCID: http://orcid.org/0000-0002-0585-5388

University of Physical Education in Cracow, Poland;

e-mail: grazyna.kosiba@awf.krakow.pl

Maria Gacek

ORCID: http://orcid.org/0000-0001-8798-3545

University of Physical Education in Cracow, Poland; e-mail: maria.gacek@awf.krakow.pl

Agnieszka Wojtowicz

ORCID: https://orcid.org/0000-0002-4589-1375

University of Physical Education in Cracow, Poland;

e-mail: agnieszka.wojtowicz@awf.krakow.pl

\title{
Preparation of Teachers and of Teaching Specialisation Students for the Implementation of School Health Education - a Review of Research
}

http://dx.doi.org/10.12775/PBE.2020.009

\begin{abstract}
Shaping health awareness is one of the basic tasks of education, hence, creating healthy attitudes of children and young people should occupy an important place among the goals of education. In Poland, the role of a teacher as a health educator has been validated in key documents related to education and upbringing: general educational curriculum and education standards preparing for the teaching profession. The implementation of health education requires extensive subject-related and pedagogical competences from teachers. The aim of this work was to review a research in the field of preparing teachers and students of teaching specialisations for the implementation of school health education, particularly concerning: knowledge about health determinants, the position of vital values (health, physical condition and well-being) in the hierarchy of values, the scale of healthy behaviours in lifestyle and
\end{abstract}


readiness to change as an important element of behaviour modification (also in the dimension of health culture). A review of the analysed studies showed a limited amount of knowledge in the field of health determinants and threats, low position of vital values in the hierarchy of values, prevalence of anti-health behaviours in lifestyle, and limited readiness of teachers and students of teaching faculties for a change regarding health-promoting behaviours.

Keywords: health education, teachers, students of teaching specialisations, professional competences.

\section{Introduction}

Shaping the health awareness of children and young people is one of the basic goals of education, in which the importance of care for health should be equated with both the existential, biological and social values of health, as well as the position of health in the value system (Kowalski, 2007). Pro-health behaviours, as behavioural determinants of health, are shaped in the process of socialisation as a result of the impact of norms and patterns functioning in an environment. The value of health is internalised through the implementation of complex educational programmes and creating conditions conducive to promoting pro-health behaviours. In this respect, a special role, next to the family, is played by school, which is obliged to create conditions for shaping the healthy attitudes and behaviours of students, including the implementation of health education.

According to the theory of social learning, teachers model students' health behaviours, and their attitude towards their health can influence the preferred model of school health education. Therefore, an important condition for fulfilling the role of a health educator is a teacher's willingness to present his/her own attitude towards health through pro-health behaviours that may serve as a role model for students (Caussidier et al., 2011; Schee \& Gard, 2014). Being aware of the importance and value of health, a teacher is a more reliable health educator. Within this context, proper preparation of teachers and teaching specialisation students in the field of knowledge about health and its determinants, their skills and methodological competences as well as pro-health attitudes and behaviours are a condition for the effective implementation of school health education and health promotion among children and the youth (Selvi, 2010; Moynihan et al., 2015).

School health education, as a significant long-term investment in public health, is an important element of the health policy in many European countries (Woynarowska, 2012; McKenzie \& Lounsbery, 2013; Chin \& Edginton, 2014; 
Storey et al., 2016). Incorporated into the basic objectives of general education, in some countries, it functions as a separate school subject (e.g. Finland, Great Britain), while in others (Poland, Germany, Spain), the content of its various aspects is found in different teaching subjects.

In Poland, the role of a teacher as a health educator has been validated in key documents for the educational and upbringing process: general education core curriculum (MEN, 2017) and educational standards preparing for the teaching profession (MNiSW, 2019). Pursuant to the assumptions of the general educational core curriculum, the obligation to implement health education was imposed on teachers of all specialisations, with emphasis placed on the special role of physical education teachers. In the current general education core curriculum from 2017, it is indicated that the purpose of health education (as one of the key tasks of the school) is to shape students' healthy attitudes, including habits related to hygiene, and to enrich knowledge on proper nutrition and the importance of physical activity (MEN, 2017). In the current standards preparing for the teaching profession, content in the field of health education was included in the area of psychological and pedagogical preparation (MNiSW, 2019). The content includes issues concerning human psycho-physical and socio-emotional development, determinants of social behaviour, disorders of functioning during adolescence, subjectivity, empathy, assertive and aggressive behaviours, decreased mood and depression, addictions and eating disorders, coping with stress, and various aspects of social communication.

\section{Competences of teachers and teaching specialisation students in the area of health education}

The implementation of health education requires extensive subject-related and pedagogical competences from teachers. Meanwhile, in research, the insufficient preparation of teachers of various specialisations to conduct school health education and a lack of interest in improving competences in this field, are indicated (Wiśniewska-Śliwińska et al., 2010; Adamiak, 2011; Woynarowska, 2012). Attention should also be paid to the lack of an effective methodological support system and infrastructure for teacher training and limited interest of universities in supporting school health education (Woynarowska, 2012; Charzyńska-Gula et al., 2013). Significant deficits in the preparation of teaching students to create health culture for future students is also noted in the research (Wrona-Wolny \& Makowska, 2011; Klimas \& Laudańska-Krzemińska, 2015; Kosiba et al., 2017a). 
When discussing preparation for the implementation of health education at schools, attention should be paid to factors potentially conditioning its effectiveness, including: level of knowledge about health, methodological competences, pro-health attitudes and behaviours, the position of health in the value system, and readiness of teachers and teaching students to change.

The key condition for shaping positive attitudes of school children and the youth towards health and health education is the reliable knowledge of teachers in this field. However, in the research, the limited amount of knowledge about health and its determinants among students (future teachers) is confirmed. In a study by Kosiba and others (2017a), it was found that more than $90 \%$ of students of teaching specialisations (including physical education) treat health as physical well-being, and $45 \%$ believe that the health of an individual and population depends, to the greatest extent, on the quality and availability of the health-care system. These results indicate the perception of health only in a physiological dimension, in accordance with the assumptions of the biomedical model and pathogenic orientation of medical sciences, departing from the modern holistic (bio-psycho-social) paradigm and salutogenic orientation of medical sciences. It has also been shown that the vast majority of students (83\%) do not understand the concept of "life skills" (most often identifying them with self-care activities), and more than $40 \%$ do not see the role of health education in strengthening self-esteem and self-evaluation, which confirms the limited understanding of the goals of contemporary health education among future teachers. Furthermore, in research among active teachers, the limited resource of knowledge has been confirmed regarding determinants and threats to health (Piekut \& Dziubanek, 2012; Nowicki et al., 2017). Among teachers working at different schools, an insufficient level of knowledge regarding the following have been noted: risk factors and prevention of chronic, including cardiovascular, diseases (Nowicki et al., 2010), environmental threats to health (Piekut \& Dziubanek, 2012), procedures for providing first-aid (Bock et al., 2014), recommendations for rational nutrition (Stankiewicz \& Bogdańska, 2013; Sharma et al., 2013), food allergies (Kowalski et al., 2009) as well as oral hygiene among children (Liontou et al., 2016).

The implementation of a healthy lifestyle is also favoured by the high position of health in the entity's value system (Kowalski, 2007). Meanwhile, the low position of vital values, including health, physical condition and wellbeing, in the hierarchy of values of students and teachers is indicated in research. In studies conducted among students of teaching specialisations at the University of Bialystok, it has been shown that vital values occupied the penul- 
timate position, before hedonistic, in the ranking of values (Dakowicz, 2006). The academic youth identified themselves most with ethical, cognitive and religious values. The importance that students - prospective teachers - attribute to health-related values has not changed significantly over the past several years. In studies conducted among students of teaching faculties at Kraków universities (Kosiba et al., 2017b), it has also been demonstrated that vital values are not highly appreciated by students (they are only in 8th place, out of 10 possible on the Schelerian Scale). The surveyed students value moral principles (goodness, honour, truthfulness, helping others) and truth-related values (intelligence, wisdom, broad mental horizons, knowledge) the highest. Different trends have been described among physical education students who attribute high importance to health-related values and place them higher or on an equal footing with love and family happiness (Szczepański, 2005). Vital values also did not obtain a high position in the teachers' hierarchy of values. In the group of 580 people (300 special education teachers and 280 of other specialisations) from Lublin and Podkarpacie, only aesthetic values were classified below vital values (Parchomiuk, 2015).

In shaping the health culture of children and youth, in addition to properly implemented educational tasks, the personal example of a teacher, who can be an appropriate role model and promote a healthy lifestyle among students through his/her pro-health behaviours, is also important. Meanwhile, the prevalence of anti-health behaviours in teachers' lifestyles is indicated in research (Prażmowska et al., 2011; Duda-Zalewska, 2012; Woynarowska-Sołdan \& Tabak, 2013; Laudańska-Krzemińska, 2015; Laudańska-Krzemińska et al., 2015). The limited scale of implementing a healthy lifestyle among teachers includes, in particular: nutritional mistakes, preferring passive rest and ineffective coping with psychological stress (Ogińska-Bulik, 2006; Zysnarska \& Bernad, 2007; Woynarowska-Sołdan \& Tabak, 2013; Sharma et al., 2013). Among physical education teachers (those who are the most responsible for modelling healthy behaviours of children and adolescents), an average level of pro-health behaviours in terms of proper eating habits, preventive behaviours, positive mental attitude and pro-health practices was demonstrated (Lipowski \& Szczepańska-Klunder, 2013). Within the context of the particularly important role of recreational physical activity for the proper psychophysical development of children and adolescents, as well as improving health potential and quality of life in the later stages of ontogenesis, research results indicating a low level of physical activity of teachers are alarming (Zysnarska \& Bernad, 2007; Prażmowska et al., 2011; Biernat et al., 2012; Brito et al., 2012; 
Webber et al., 2012; Woynarowska-Sołdan \& Tabak, 2013). Physical education teachers, who significantly more actively participate in physical culture (Laudańska-Krzemińska, 2015), do not fit into these tendencies. The low scale of teachers' pro-health behaviours corresponds to the results of other studies in which the prevalence of various health problems, including mental diseases and psychosomatic disorders among teachers, has been indicated (Seibt et al., 2013; Scheuch et al., 2015). A limited level of pro-health behaviours has also been demonstrated among students with a teaching educational profile. In studies among academic youth in teaching faculties, the low participation of students in physical activity has been confirmed (Mędrela-Kuder, 2011; RomanowskaTołloczko, 2011; Podstawski et al., 2012; Palacz, 2014; Deasy et al., 2015; Kosiba et al., 2016; Monhollen et al., 2016), as well as the increasing occurrence of nutritional irregularities and errors (Walentukiewicz, 2010; RomanowskaTołłoczko, 2011; Rasińska, 2012; Palacz 2014). The low level of pro-health behaviours among students also concerned preventive measures, among others, according to Inwentarz Zachowań Zdrowotnych [The Inventory of Health Behaviours] by Z. Juczyński (2012), compliance with medical recommendations, regular preventive check-ups and gaining knowledge about health determinants and threats (Nitecka-Walerych, 2005; Kosiba et al., 2016). In addition, despite the knowledge of the pathophysiological properties of psychoactive substances, the academic youth often reach for alcoholic beverages (Lysak et al., 2009) and tobacco products (Lisicki \& Kosińska, 2010; Romanowska-Tołłoczko, 2011).

The optimal level of readiness for a change is also conducive to enriching teachers' competences to implement school health education. Readiness to change is defined as the subjective perception of the requirements of the environment, associated with specific emotional states, cognitive processes and behavioural elements, resulting from the interpretation of objective reality (Kriegel \& Brandt, 1996). In one of the models of readiness for change (Kriegel \& Brandt, 1996), seven indicators were distinguished, including: ingenuity, passion, selfconfidence, optimism, risk-taking, adaptability (flexibility and resilience) and tolerance of uncertainty. A person with an optimal readiness-to-change profile can effectively implement ideas, is positive about reality, active and open to new challenges, aware of competences and adapts well to environmental conditions (Kriegel \& Brandt, 1996). Readiness to change fits in with the essence of modern models of changing health behaviours, including the transtheoretical model, concerning the phased introduction, continuation and maintenance of health-promoting behaviours, which was confirmed among students in the area of modelling the level of physical activity, elimination of nutritional errors and 
diet rationalisation as well as limitation of alcohol consumption (Harris et al., 2008; Kazemi et al., 2012; Dae-Jung et al., 2014; Han et al., 2017). Moreover, in research among teachers, it has been confirmed that readiness to change is one of the factors conditioning the development of professional competences, also in the dimension of health culture (Leśniewska, 2016; Yusuf \& Gil, 2016; Winardi \& Prianto, 2016; Kondakci et al., 2017). However, in research by Leśniewska (2016), the limited readiness for changes among teachers was demonstrated. This varied depending on age and experience, with an indication of greater openness to changes among younger teachers. Teachers' low willingness to change behaviours related to their health problems has also been confirmed in Brazilian studies (Rossi-Barbosa et al., 2015). The importance of teachers' readiness to change for the effective functioning of the education system has also been highlighted in Malaysia (Aziz et al., 2015). In other studies, it has been shown that an important predictor of teachers' willingness to change is trust in school as an institution (Zayim \& Kondakci, 2014; Kondakci et al., 2017). Within this context, the supportive role of the school environment, cooperating to obtain such a school culture, should be pointed out, in which teacher communication and mutual relations are particularly strengthened and appreciated, becoming a "vital" force in periods of change. Research results also showed that teachers working at smaller schools are more likely to accept and implement changes, in which cooperation, mutual commitments and support imply greater willingness and desire to participate in changes (Zayim \& Kondakci, 2014). In the education system, knowledge about the level of readiness of teachers to change can be an important instrument of the effective functioning of a school, also in the area of health education of school children and the youth.

\section{Conclusions}

Nowadays, the role of a teacher is not limited to teaching and upbringing, but refers to a wide spectrum of cultural, cognitive and civilization factors. Within the context of numerous threats to holistically defined health, education regarding the health of children and adolescents in the area of its behavioural, psycho-social and environmental determinants, may be an important factor in promoting health and early prevention of chronic diseases at later stages of ontogenesis. Thanks to the efforts of many generations of experts and teachers, health education is now becoming an important area of general education, implemented by teachers of all specialisations, with emphasis on the special role of physical 
education teachers. However, not all teachers, including those teaching physical education, have accepted changes in the core-curriculum regarding health education. Indeed, they see the need to educate students about health, but this area of education is still treated marginally at school (Zadarko-Domaradzka et al., 2014). The primary activity of schools is focused on educational results, neglecting students' health problems. In many countries, the status of school health education is still low, and school staff, mainly teachers, are unaware of their role in shaping health-promoting behaviours and health promotion. In research, it has been shown that teachers (and students) who have undergone relevant training in health education and also place health high in their value hierarchy, are more likely to engage in health promotion projects and present a more comprehensive approach to health education (Didier et al., 2008; Kosiba et al., 2019). Therefore, assuming that the preferred values direct human activity, and modern health education is education towards different body-related values (aesthetic, hedonistic, agonist, utilitarian and vital), in the education of students - future teachers - attention should be paid not only to the preparation of knowledge and skills concerning the protection and increasing health, but also on the value of holistically defined health.

\section{References}

Adamiak, J. (2011). Edukacja zdrowotna w opinii nauczycieli szkół podstawowych i gimnazjum [Health Education in the Opinion of Primary and Junior-high School Teachers]. Wychowanie Fizyczne i Zdrowotne, 3, 12-18.

Aziz, A.A.A., Fooi, F.S., Asimiran, S., \& Hassan, A. (2015). Literature Review on the Relationship Between Principal Instructional Leadership and Teacher Readiness to Implement Change. International Refereed Research Journal, 6(1), 12-19.

Bartyzel-Lechforowicz, H. (2010). Znajomość problematyki udaru mózgu wśród nauczycieli i uczniów [Knowledge of the Problem of Stroke Among Teachers and Students]. Hygeia Public Health, 45(1), 74-79.

Biernat, E., Poznańska, A., \& Gajewski, A.K. (2012). Determinants of Health Oriented Physical Activity among Warsaw Teachers. Przeglad Epidemiologiczny, 66(1), 119-126.

Bock, A., Kuźmiński, A., Chabowski, M., Goldman, J., \& Bujnowska, M. (2014). Wiedza przedszkolnych nauczycieli na temat zasad udzielania pierwszej pomocy dzieciom [The Knowledge of the Teachers in Kindergarten About Pediatric BLS Procedures]. Pielegniarstwo i Zdrowie Publiczne, 4(4), 345-350.

Brito, W.F., Santos, C.L., Marcolongo Ado, A., Campos, M.D., Bocalini, D.S., Antonio, 
E.L., Silva Junior, J.A., Tucci, P.J., \& Serra, A.J. (2012). Physical Activity in Public School Teachers. Revista de Saude Publica, 46(1), 104-109, doi: 10.1590/s003489102012000100013.

Caussidier, C., El Hage, F., Munoz, F., Remki, L., Larribi, R., Khzami S.E., Berger, D., de Carvalho, G.S., \& Favre, D. (2011). In Search of a Health Education Model: Teachers' Conceptions in Four Mediterranean Countries. Global Health Promotion, 18(4), 5-15, doi: $10.1177 / 1757975911422962$.

Charzyńska-Gula, M., Sygit, K., Sygit, M., Goździewska, M., Dobrowolska, B., \& Gałęziowska, E. (2013). Problems of Health Education in Rural Areas in Poland. Annals of Agricultural and Environmental Medicine, 20(3), 515-522.

Chin, M.K., \& Edginton, C.R. (2014). Physical Education and Health. Global Perspectives and Best Practice. Sagamore Publishing LLC.

Dae-Jung, J., Ki-Jong, K., \& Myoung, H. (2014). Factors Related to Stages of Exercise Behavior Change Among University Students Based on the Transtheoretical Model. Journal of Physical Therapy Science, 26(12), 1929-1932, doi: 10.1589/jpts.26.1929.

Dakowicz, L.A. (2006). Świat wartości przyszłych nauczycieli: studium socjologiczne na podstawie badań studentów specjalizacji nauczycielskiej Uniwersytetu w Białymstoku [The World of Values Among Future Teachers: Sociological Study Based on Research Among Teaching Specialisation Students from the University of Biatystok]. Białystok: Trans Humana.

Deasy, C., Coughlan, B., Pironom, J., Jourdan, D., \& Mcnamara, P.M. (2015). Psychological Distress and Lifestyle of Students: Implications for Health Promotion. Health Promot International, 30(1), 77-87, doi: 10.1093/heapro/dau086.

Didier, J., Oddrun, S., Fatou, D., \& Carvalho, G.S. (2008). The Future of Health Promotion in Schools Goes through the Strengthening of Teacher Training at a Global Level. Promotion \& Education, 15(3), 36-38, doi: 10.1177/1025382308095657.

Duda-Zalewska, A. (2012). Zachowania zdrowotne nauczycieli a staż pracy w zawodzie [Teachers' Health Behaviors Versus their Professional Seniority]. Hygeia Public Health, 47(2), 183-187.

Han, H., Gabriel K.P., \& Kohl, H.W. (2017). Application of the Transtheoretical Model to Sedentary Behaviors and its Association with Physical Activity Status. PLoS One, 12(4), e0176330, doi: 10.1371/journal.pone.0176330.

Harris, T.R., Walters, S.T., \& Leahy, M.M. (2008). Readiness to Change Among a Group of Heavy-Drinking College Students: Correlates of Readiness and a Comparison of Measures. Journal of American College Health, 57(3), 325-330, doi: 10.3200/ JACH.57.3.325-330. 
Juczyński, Z. (2012). Narzędzia pomiaru w promocji i psychologii zdrowia [Measurement Tools in Promotion and Health Psychology]. Warszawa: Pracownia Testów Psychologicznych.

Kazemi, D.M., Wagenfeld, M., Van Horn, K.R., Levine, M.J., \& Dmochowski, J. (2011). Binge Drinking Among Underage College Students: Role of Impulsivity and the Transtheoretical Model. Journal of Addictions Nursing, 22(4), 193-199, doi: 10.3109/1088 4602.2011.616605.

Klimas, N., \& Laudańska-Krzemińska, I. (2015). Przygotowania studentów wychowania fizycznego do prowadzenia zajęć z zakresu edukacji zdrowotnej - teoria a rzeczywistość [The Preparation of Physical Education Students for Health Education Lessons - Theory and Reality]. Quality in Sport, 1(2), 43-52, doi: 10.12775/QS.2015.010.

Kondakci, Y., Beycioglu, K., Sincar, M., \& Ugurlu, C.T. (2017). Readiness of Teachers for Change in Schools. International Journal of Leadership in Education, 20(2), 176-197, doi: 10.1080/13603124.2015.1023361.

Kosiba, G., Gacek, M., Bogacz-Walancik, A., \& Wojtowicz, A. (2016). The Lifestyle of Students - Future Teachers. Antopomotoryka. Journal of Kinesiology and Exercise, 74(26), 83-94, doi: 10.5604/01.3001.0009.5616.

Kosiba, M., Bogacz-Walancik, A., Wójtowicz, A., \& Gacek, M. (2017a). Obszary wiedzy z zakresu edukacji zdrowotnej wśród studentów wychowania fizycznego i innych specjalności nauczycielskich [Knowledge in the Feld of Health Education among Students of Physical Education and other Teacher Education Faculties]. Rozprawy Naukowe AWF we Wroctawiu, 58, 79-88.

Kosiba, G., Gacek, M., Bogacz-Walancik, A., \& Wójtowicz, A. (2017b). Wartości witalne w hierarchii wartości a styl życia studentów kierunków nauczycielskich [Vital Values in the Hierarchy of Values and the Lifestyle of Student Teachers]. Przeglad Badań Edukacyjnych, 24(1), 21-40, doi: 10.12775/PBE.2017.002.

Kosiba, G., Bogacz-Walancik, A., Gacek, M., Wojtowicz, A., \& Majer, M. (2019). Vital Values and Physical Activity of Future Teachers. Human Movement 20(1), 75-82, doi: $10.5114 / \mathrm{hm} .2019 .77836$.

Kowalski, M. (2007). Zdrowie i kultura zdrowotna - różne perspektywy poznawcze [Health and Health Culture - Various Cognitive Perspectives]. In: M. Kowalski, \& A. Gawel (Eds.), Zdrowie - Wartość - Edukacja [Health - Value - Education], (pp. 13-105). Kraków: Oficyna Wydawnicza Impuls.

Kowalski, M., Majkowska-Wojciechowska, B., Wardzyńska, A., Wysocka, M., \& Kowalski, M. (2009). Stan wiedzy personelu szkół podstawowych na temat alergii na pokarmy [The Level of Food Allergy Knowledge among Primary School Personnel]. Alergia Astma Immunologia, 15(2), 113-120. 
Kriegel, R., \& Brandt, D. (1996). Sacred Cows Make the Best Burgers. Developing Change-ready People and Organizations. New York: Warner Books.

Laudańska-Krzemińska, I. (2014). Health Behaviours and their Determinants among Physical Education and Pedagogy Students as well as School Teachers - a Comparison Study. Acta Universitatis Carolinae Kinanthropologica, 50(2), 69-78.

Laudańska-Krzemińska, I., Wierzejska, E., Jóźwiak, P., \& Klimas, N. (2015). Zachowania zdrowotne nauczycieli w Wielkopolsce - poszukiwanie mocnych i słabych stron [Pro-health Behaviours of Teachers in the Wielkopolska Voivodeship]. In: R. Stemplewski, R. Szeklicki, \& J. Maciszek (Eds.), Aktywność fizyczna i żywienie w trosce o zdrowie i jakość życia [Physical Activity and Nutrition for the Sake of Health and Quality ofLlife], (pp. 231-242). Poznań: Bogucki Wyd. Naukowe.

Leśniewska, G. (2016). Gotowość do zmiany nauczycieli szansą edukacji XXI wieku [Ready To Change the Teachers a Chance of Education XXI Century]. Studia i Prace WNEIZ US, 46(1), 39-49, doi:10.18276/sip.2016.46/1-03.

Liontou, V., Agouropoulos, A., Gizani, S., \& Papagiannoulis, L. (2016). Knowledge of Preschool Teachers in the Prefecture of Attica of Early Childhood Oral Health. Association with their Demographic and Personal Characteristics. European Archives of Paediatric Dentistry, 17(6), 467-474.

Lipowski, M., \& Szczepańska-Klunder, Ż. (2013). Zachowania zdrowotne nauczycieli wychowania fizycznego [Pro-health Behaviours of Physical Education Teachers]. In: Z. Jastrzębski (Ed.), Teoria i praktyka wychowania fizycznego i sportu [Theory and Practice of Physical Education and Sport], (pp. 9-26). Łódź: Wyższa Szkoła Sportowa w Łodzi.

Lisicki, T., \& Kosińska, E. (2010). Krytycznie o badaniach czasu wolnego młodzieży akademickiej [Critically on Research Regarding Leisure Time of the Academic Youth]. Zdrowie - Kultura zdrowotna - Edukacja, 5, 49-57.

Łysak, A., Walentukiewicz, A., \& Wilk, B. (2009). Wybrane zachowania zdrowotne młodzieży akademickiej o wysokim poziomie aktywności fizycznej - doniesienia wstępne [Chosen Health Behaviours in Academic Youth Intensively Practicing Physical Activitym - an Inception Paper]. Rocznik Naukowy AWFiS, Gdańsk, 19, 113-127.

Mckenzie, T., \& Lounsbery, M.A. (2013). Physical Education Teacher Effectiveness in a Public Health Context. Research Quarterly Exercise and Sport, 84(4), 419-430, doi: 10.1080/02701367.2013.844025.

Mędrela-Kuder, E. (2011). Ocena stylu życia studentów fizjoterapii i edukacji techniczno-informatycznej na podstawie żywienia i aktywności fizycznej [Evaluation of the Life Style of Physiotherapy and Technical-computer Science Students as a Case Study Per- 
taining to Diet and Physical Activity]. Roczniki Państwowego Zakładu Higieny, 62(3), 315-318.

Monhollen, C., Summers, L., Sabin, M., \& Rutherford, J. (2016). Sedentary Behaviors and Physical Activity in Relation to Class Standing in University Students. Medicine \& Science in Sports \& Exercise, 48(5 Suppl 1), 1063, doi: 10.1249/01.mss.0000488198.25704. eb.

Moynihan, S., Paakkari, L., Välimaa, R., Jourdan, D., \& Mannix-McNamara, P. (2015). Teacher Competencies in Health Education: Results of a Delphi Study. PLoS ONE, 10(12), e0143703, doi: 10.1371/journal.pone.0143703.

Nitecka-Walerych, A. (2005). Zachowania prozdrowotne studentów pedagogiki wczesnoszkolnej [Pro-health Behaviours of Early-school Teaching Specialisation Students]. In: T. Lisicki, B. Wilk, \& A. Walentukiewicz (Eds.), Prozdrowotny styl życia [A Healthy Lifestyle], (pp. 291-298). Gdańsk: AWFiS.

Nowicki, G.J., Ślusarska, B., Kocka, K., \& Piasecka, H. (2017). Stan wiedzy na temat czynników ryzyka i profilaktyki chorób cywilizacyjnych a zachowania zdrowotne pracowników medycznych i niemedycznych [The Level of Knowledge Regarding Risk Factors and Prevention of Lifestyle Diseases in Relation to Health Behaviour among Medical and Non-medical Professionals]. Medycyna Środowiskowa, 20(1), 41-17, doi: 10.19243/2017105.

Ogińska-Bulik, N. (2006). Stres zawodowy w zawodach ustug społecznych. Źródła - Konsekwencje - Zapobieganie [Professional Stress in Social Service-related Occupations. Sources - Consequences - Prevention]. Warszawa: Difin.

Palacz, J. (2014). Zachowania zdrowotne studentów w świetle wybranych uwarunkowań [Health Behaviours of Students in the Light of Selected Conditioning]. Medycyna Ogólna i Nauki o Zdrowiu, 20(3), 301-306.

Parchomiuk, M. (2015). Value Preferences of Teachers and their Attitudes Towards Individuals with Disabilities. International Journal of Disability, Development and Education, 62(3), 276-287, doi: 10.1080/1034912X.2015.1020919.

Piekut, A., \& Dziubanek, G. (2012). Środowiskowe zagrożenia zdrowia w świadomości różnych grup społecznych województwa śląskiego [Awareness of Environmental Health Risks in Selected Social Groups in Silesian Voivodeship]. Annales Academiae Medicae Silesiensis, 66(5), 34-44.

Podstawski, R., Górnik, K., \& Romańczuk, A. (2012). Styl życia przyszłych nauczycielek wczesnej edukacji kształcących się na Uniwersytecie Warmińsko-Mazurskim w Olsztynie [Lifestyles of Future Teachers of Early Education Studying at the University of Warmia and Mazury in Olsztyn]. Hygeia Public Health, 47(1), 95-99. 
Prażmowska, B., Dziubak, M., Morawska, S., \& Stach, J. (2011). Wybrane zachowania zdrowotne nauczycieli szkół średnich [Selected Aspects of Secondary School Teachers' Healthful Behaviour]. Problemy Pielęgniarstwa, 19(2), 210-218.

Rasińska, R. (2012). Nawyki żywieniowe studentów w zależności od płci [Dietary Habits of Students Depending on the Sex]. Nowiny Lekarskie, 81(4), 354-359.

Romanowska-Tołłoczko, A. (2011). Styl życia studentów oceniany w kontekście zachowań zdrowotnych [University Students' Lifestyles in the Context of Their Health Behaviors]. Hygeia Public Health, 46(1), 89-93.

Rossi-Barbosa, L.A., Gama, A.C., \& Caldeira, A.P. (2015). Association Between Readiness for Behavior Change and Complaints of Vocal Problems in Teachers. Codas, 27(2), 170-177, doi: 10.1590/2317-1782/20152013088.

MEN [Ministry of National Education] (2017). Rozporządzenie Ministra Edukacji Narodowej z dnia 14 lutego 2017 r. w sprawie podstawy programowej wychowania przedszkolnego oraz podstawy programowej kształcenia ogólnego dla szkoły podstawowej, w tym dla uczniów z niepełnosprawnością intelektualną w stopniu umiarkowanym lub znacznym, kształcenia ogólnego dla branżowej szkoły I stopnia, kształcenia ogólnego dla szkoły specjalnej przysposabiającej do pracy oraz kształcenia ogólnego dla szkoły policealnej [Ordinance of the Minster of National Education from 14 Feb. 2017 regarding the core-curriculum of pre-school education and the core-curriculum of general education for primary schools, including students with moderate or severe mental disabilities, general education for $1^{\text {st }}$ degree trade schools, general education for specials schools preparing for professional work and general education for post-secondary schools] (Dz. U. 2017, poz. 356) [Journal of Laws 2017, item 356].

MEN [Ministry of National Education] (2018). Rozporządzenie Ministra Edukacji Narodowej z dnia 30 stycznia 2018 r. w sprawie podstawy programowej kształcenia ogólnego dla liceum ogólnokształcącego, technikum oraz branżowej szkoły II stopnia [Ordinance of the Minster of National Education from 30 Jan. 2018 regarding the core-curriculum of general education for secondary schools, technical schools and $2^{\text {nd }}$ degree trade schools] (Dz. U. 2018, poz. 467) [Journal of Laws 2018, item 467].

MEN [Ministry of National Education] (2019). Rozporządzenie Ministra Nauki i Szkolnictwa Wyższego z dnia 25 lipca 2019 r. w sprawie standardu kształcenia przygotowującego do wykonywania zawodu nauczyciela [Ordinance of the Minster of National Education from $25 \mathrm{Jul} .2019$ regarding the standards of education preparing for the teaching profession (Dz. U. 2019, poz. 1450) [Journal of Laws 2019, item 1450].

Schee, C.V., \& Gard, M. (2014). Healthy, Happy and Ready to Teach, or why Kids can't Learn from Fat Teachers; the Discursive Politics of School Reform and Teacher Health. Critical Public Health, 24(2), 210-225. 
Scheuch, K., Haufe, E., \& Seibt, R. (2015). Teachers' Health. Deutsches Ärzteblatt International, 112(20), 347-356, doi: 10.3238/arztebl.2015.0347.

Seibt, R., Spitzer, S., Druschke, D., Scheuch, K., \& Hinz, A. (2013). Predictors of Mental Health in Female Teachers. International Journal of Occupational Medicine Environmental Health, 26(6), 856-869, doi: 10.2478/s13382-013-0161-8.

Selvi, K. (2010). Teachers' Competencies. Cultura International Journal of Philosophy of Culture and Axiology, 7(1), 167-75.

Sharma, S., Dortch, K.S., Byrd-Williams, C., Truxillio, J.B., Rahman, G.A., Bonsu, P., \& Hoelscher, D. (2013). Nutrition-related Knowledge, Attitudes, and Dietary Behaviors among Head Start Teachers in Texas: a Cross-sectional Study. Journal of the Academy of Nutrition and Dietetics, 113(4), 558-562, doi: 10.1016/j.jand.2013.01.003.

Stankiewicz, J., \& Bogdańska K. (2013). Ocena poziomu wiedzy żywieniowej pracowników przedszkoli w zakresie prawidłowego żywienia dzieci w wieku przedszkolnym [Assessment of the Extent of Nutritional Awareness among Kindergarten Employees in Terms of Proper Nutrition of Preschool Children]. Problemy Higieny i Epidemiologii, 94(3), 479-483.

Storey, K.E., Montemurro, G., Flynn, J., Schwartz, M., Wright, E., Osler, J., Veugelers, P.J., \& Roberts, E. (2016). Essential Conditions for the Implementation of Comprehensive School Health to Achieve Changes in School Culture and Improvements in Health Behaviours of Students. BMC Pubic Health, 16(1), 1133, doi: 10.1186/s12889-0163787-1.

Szczepański S. (2005), Zdrowie w systemie wartości studentów wychowania fizycznego [Health in the System of Values Among Physical Education Students]. Annales Universitatis Mariae Curie-Skłodowska, Lublin, sectio D, vol. LX, suppl. XVI, 526, 74-78.

Walentukiewicz, A. (2010). Ocena wartości odżywczej diet studentek AWFiS w Gdańsku. Cz. II. Witaminy i składniki mineralne [An Assessment of Nutritional Value of Diets of Female Students of Physical Education Department at AWFiS in Gdansk. Part II. Vitamins and Minerals]. Rocznik Naukowy AWFiS w Gdańsku, t. 20., 108-114.

Webber, L.S., Rice, J.C., Johnson, C.C., Rose, D., Srinivasan, S.R., \& Berenson, G.S. (2012). Cardiovascular Risk Factors an Physical Activity Behavior among Elementary School Personnel: Baseline Results from the ACTION! Worksite Wellness Program. The Journal of School Health, 82(9), 410-416, doi:10.1111/j.1746-1561.2012.00716.x.

Winardi, \& Prianto, A. (2016). Various Determinants of Individual Readiness to Change and Their Effects on the Teachers' Performance (A Study on Certified Teachers in Jombang Regency East Java, Indonesia). IOSR J Business Manag (OISR-JBM), 18(2), 22-32. 
Wiśniewska-Śliwińska, H., Marcinkowski, J.T, \& Wiśniewski, S.A. (2010). Opinie nauczycieli wychowania fizycznego względem propozycji ustanowienia ich głównymi edukatorami zdrowotnymi w szkołach [Opinions of Physical Education Teachers Regarding a Proposal of Appointing them Main Health Educators at Schools]. Problemy Higieny i Epidemiologii, 45(2), 206-212.

Woynarowska, B. (2012). Edukacja zdrowotna w nowych standardach kształcenia nauczycieli [Health Education in the New Standards of Pro-health Education]. Wychowanie Fizyczne i Zdrowotne, 5, 4-10.

Woynarowska-Sołdan, M., \& Tabak, I. (2013). Zachowania prozdrowotne nauczycieli i innych pracowników szkoły [Health Enhancing Behaviors of Teachers and other School Staff]. Medycyna Pracy, 64(5), 659-670.

Wrona-Wolny, W., \& Makowska B. (2011). Opinie studentów - przyszłych nauczycieli wychowania fizycznego dotyczące realizowanych przez nich zajęć z edukacji zdrowotnej w szkole [Opinions of Students - Future Teachers of Physical Education - on Health Education Lessons Conducted by them at School]. Hygeia Public Health, 46(4), $477-483$.

Yusuf, İ., \& Gil, F. (2016). Relationship of Teachers' Readiness for Change with their Participation in Decision Making and School Culture. Educational Research Review, 11(8), 823-833, doi: 10.5897/ERR2016.2730.

Zadarko-Domaradzka, M., Matłosz, P., \& Warchoł, K. (2014). Edukacja zdrowotna w szkolnej praktyce procesu wychowania fizycznego [Health Education in School Implementation of Physical Education Process]. Problemy Higieny i Epidemiologii, 95(3), $673-678$.

Zayim, M., \& Kondakci, Y. (2014). An Exploration of the Relationship between Readiness for Change and Organizational Trust in Turkish Public Schools. Educational Management Administration \& Leadership, 43(4), 610-625, doi: 10.1177/1741143214523009.

Zysnarska, M., \& Bernad, D. (2007). Zachowania prozdrowotne nauczycieli w województwie wielkopolskim - część I. [Health Behavior of Teachers in the Wielkopolska Province - Part I]. Problemy Higieny i Epidemiologii, 88(2), 183-187. 